\title{
Financing Social Development in South Africa: A Case of Rural-Based NGOS in The Health Sector
}

\author{
Miriam Hofisi \\ North-West University, Department of Development Studies \\ Email:mvhutuza@gmail.com \\ Costa Hofisi, PhD \\ North-West University, Department of Public Administration. \\ Email: Costa.Hofisi@nwu.ac.za
}

\section{Doi:10.5901/mjss.2013.v4n6p523}

\begin{abstract}
The objective of this article is to assess the funding strategy of the government in relation to the sustainability of the work of NGOs in South Africa. This was achieved through analysing the guiding principles of the government in terms of disbursing funds and how this affects NGO operations. The article is based on a qualitative case study research design while employing the historical approach. Findings indicate that funding is shrinking and also that rural-based NGOs fail to meet complex funding requirements and some have downsized while others are closing. The study recommends that the government must streamline funding requirements to reach out to the rural-based NGOs.
\end{abstract}

Keywords: Non-Governmental Organisations; funding strategy; sustainability

\section{Introduction}

Non-governmental organisations in South Africa used to operate under the repression of the discriminatory apartheid government. When most political parties were banned, activists opted to operate as advocacy NGOs. The apartheid parliament passed a number of legislations that created hostility between the government and Black-run NGOs. Some of them are the Fundraising Act of 1978 which made it a crime to solicit funds or receive donations unless it was directed by the Director of Fundraising. The Affected Organisations Act 31 of 1971, also prevented all organisations involved in antiapartheid activities from receiving funds from outside South Africa while The Disclosure of Foreign Funding Act 26 of 1989 required organisations to report all funds received to government. As a result, activists opted to operate covertly and received funding through illegal means. This was done with little accountability and strategic planning to the donors.

The work that is being carried out by NGOs contributes about $30 \%$ of public services in South Africa. Owing to the high unequal wealth distribution, South Africa has infant mortality rates of 43 per 1000 live births and a maternal mortality rate of 625 per 100000 despite the fact that it is a middle income country. The country has $0.6 \%$ of the world's population but has $17 \%$ of the world's HIV infections and $11 \%$ of the world's tuberculosis cases. It is against this backdrop that NGOs have found a niche in helping the poor who cannot afford to help themselves.

For a protracted period, these organisations have encountered a multiplicity of challenges, chief among them being funding. Some donors are withdrawing their funding while others are also reducing their donations owing to the global economic meltdown while others are of the opinion that the South African economy can take care of its social services due to its high Gross Domestic Product. Since 2008, NGOs have experienced an accelerated funding crisis with some organisations closing down downsizing. As a result, NGOs have been compelled to search for solutions to build resilience.

With the advent of the new democratic government, most of key personnel in the sector left for government since the political environment was now free, thus a tremendous institutional loss was incurred. At the same time, NGOs were faced with donors that had complicated and stringent criteria which were new to them. The position of NGOs was also compounded by the fact that these organisations had weak organisational skills given that they did not develop planning skills over the years that they were operating. Moreover, the government also tried to forge a new partnership with these NGOs in order to support them but that was met with institutional challenges too (Habib \& Taylor, 1999). Schneider \& 
Gilson (1999) point out that the issue of incompetence was instrumental to the funding crisis. They argue that the new government inherited a chaotic administration that had little institutional experience of conventional development aid. Other authors like Bond (2003) argue that the new government was inexperienced in handling large amounts of grants.

The funding strategy of the government has got rudiments in it that are causing the funding crisis on the part of NGOs in rural areas that assist the poor with HIVIAIDS and TB. Therefore, the major objective of the article is to assess the funding strategy of the government in relation to the sustainability of the work of NGOs. At the moment, NGOs in rural areas are facing a funding crisis whereby some are closing down and others are scaling down. This has been complex in that most of the victims who receive help from these NGOs have limited alternatives that they can resort to for survival. Moreover, there is a noticeable difference between urban-based NGOs and the rural ones in terms of accessing government funding.

\section{NGOs and Development Finance}

NGOs in South Africa have encountered an institutional crisis that needs intervention to avoid closure of some of these organisations. Buyck in McGill (1995) regards institutional development as the creation or reinforcement of the capacity of an organisation to generate, allocate and use human and financial resources effectively to attain development objectives, public or private. McGill (1995) further stressed that what makes institutional development relevant is its dynamic nature. It caters for the internal factors like organisational strengthening and restructuring as well as the external issues that concern the process which allows the organisation to respond to its development environment. Moreover, it is concerned with the policy context within which the organisation performs. In this case, government action in terms of policy also determines the sustainability of NGOs given that it is the one that funds these organisations.

NGOs maybe defined as all organisations within the aid channel that are institutionally separated from the state apparatus and are non-profit distributing (Tvedt, 1998: 12). This definition is based on the opinion that any justification for the NGO claim to advance the public interest should be demonstrated in their ability to provide relief and deliver services to their beneficiaries. The extent to which this obligation is fulfilled can be determined by how much of an NGO's money goes into good causes (Brown \&Kalegaonkar, 2002).

Although the government came up with ways of ensuring partnerships with the NGOs through the promulgation of laws like the Non-Profit Act of 1997, NGOs found it difficult to operate (Habib\& Taylor, 1999). Some institutional impediments like complex tendering procedures inherited from the previous regime that favoured the private sector contributed to the failure of NGOs to operate viably. In the same vein, the implementation of GEAR brought changes to the social contract between the government and NGOs because it favoured for-profit sectors. NGOs found themselves in a neo-liberal environment where they were operating under the market dictates that are reminiscent of capitalism and therefore did not promote the social welfare of the poorest of the society. As a result, some NGOs charged user fees, others closed down and their role became less relevant in the South African development context. Therefore, the effect of this was a continuous marginalisation of the poor.

Moreover, the fact that most high profile personnel in the sector left to join the government meant that there was tremendous institutional memory loss which left most NGOs as weaker institutions. McGill (1995) suggests that institutional weakness constitutes a roadblock to development in developing countries. The correlation between institutional development and project sustainability is essential in ensuring longevity of project life (McGill, 1995). Thus institutional development is hinged on the ability of both the government to create an enabling environment and the NGOs to develop a strong organisation that can sustain the poor.

The major objective of this study is to assess the funding strategy of the government in relation to the sustainability of the work of NGOs. This has been achieved through analysing the guiding principles and prerequisites of the government in terms of procedures of disbursing funds to NGOs and how this affects NGO operations. The organisations responsible for the disbursement of funds to NGOs that this study examined are the NDA, the NLDTF and the DoSD.

\section{Research design}

This is a case study based assessment of NGOs in the health sector from the Eastern Cape Province. This study is an assessment of the funding strategy that the government has employed to fund NGOs. The assessment was based on the guiding principles and pre-requisites of the NDA, the Department of Social Development, the Department of Health and the National Development Trust Fund in terms of disbursement of funds. In operationalising this, the study has used questionnaires and in-depth interviews with three NGOs namely Alice Hospice, Ethembeni and Laphumikwezi. Other 
organisations interviewed were the NDA, the Department of Social Development officials and the Eastern Cape NGO Coalition, Rural Livelihoods (RULIV), Community Chest and World Vision. Three other NGOs were taken as case studies from a report compiled by RULIV including Mida, Sinikuthando and Sakhubunye. Discussions with NGO and government officials allowed the researcher to gain insight into the views of the officials from NGOs and the government in relation to the viability of the funding strategy. Moreover, the use of organisations that are outside the government also helped the researcher to get independent views that helped to establish the reliability and validity of the study by not relying on one source.

\section{Findings}

Since the Paris Declaration of 2005, there has been increased emphasis by both donors and governments on the need for bilateral donors to engage the government by channelling funds to NGOs through the government. This emphasis follows the realisation by donors that aid is not ameliorating the lives of the poor. The Paris Declaration of 2005 is an agreement between governments and donors to maximise aid effectiveness through increased involvement of the government and the South African government is a signatory too. The Declaration was in line with the position of the South African government which, since 1994, started to encourage bilateral donors to channel funds to NGOs through it as transitional support. Funds to NGOs since then have been disbursed through various government departments and agencies. Although this was done in the name of aid effectiveness, there are more challenges encountered. Many NGOs are failing to scale up their activities while others are faced with the prospects of closure as funding is reaching a minority of the total number of NGOs. As ECNGOCO reiterated, funding is not getting to NGOs as it should. In a bid to survive, some NGOs are privatising while those which cannot face the tide are closing down. Consequently, the poor are the hardest hit because they do not have the resources to fend for themselves.

\subsection{NGO Operations: Their Successes.}

Despite the crisis, Alice Hospice indicated that it has managed to offer HIV and AIDS services to a clientele of more than 800 people. Of these, 340 are on Anti-Retro Viral drugs. They have managed to utilise the money that they get from Amathole District Municipality. With the aid of the European Union, their volunteers have been trained. They do offer pre and post bereavement counselling to their beneficiaries. Sakhubhunye has also managed to offer Tuberculosis and HIV and AIDS services. It serves a clientele of 450 people. Mida also offer material support to HIV and AIDS victims. The Raphael Centre also offers comprehensive counselling to its beneficiaries while it offers HIV and AIDS testing and caters for HIV victims through material support. Since these organisations are situated in poor communities where people may not have sufficient sources of income, they assist with documentation so that these poor may access government funding. In addition, they raise awareness to the poor. They have had challenges that emanate from institutional impediments as listed below.

\subsection{Operational Challenges.}

As a result of lack of adequate funding, NGOs indicated that they do not have transport they need to raise awareness in remote areas. In addition, when travelling, their volunteers use their stipends to visit patients. The money that these volunteers get is often distributed among organisation members in order of educational qualifications. This has caused conflicts among NGO members given that they do the same work. Besides conflicts, there has been high volunteer turnover, with others leaving for better opportunities. This also shows that volunteers are not offering themselves in the true spirit of helping but seeking opportunities. This is costly to the NGOs who are forced to recruit frequently with scant resources. However, this can also be an indicator that volunteers need motivation given that they are an overworked people. Besides this, Ethembeni also needed an office to work from as well as keeping their documentation. It also needed a satellite testing centre since it is located in remote areas where people travel for such services. Sakhubhunye also indicated the same. The NGOs also indicated that they need material for campaigning. These organisations sometimes resort to handwriting their own campaign material. Ethembeni indicated that it is not sure if they are going to continue given that their funding is ending. The Raphael Centre is also facing the prospect of closure if its financial situation does not improve by November 2012. Not only does this situation haunt the Eastern Cape Province. In the Western Cape, the Rape Crisis is also pestered by the prospect of closure. These organisations had already cut down some activities in the face of the crisis. 


\section{Discussion}

\subsection{The requirement of registration: Information communication.}

Mechanisms in place through the DoSD are designed in such a way that established NGOs are the ones which make use of information available for NGOs. According to the DoSD, 73\% of Trusts and 59\% of Section 21 companies managed to access model documents while $57 \%$ of Voluntary Associations and $40 \%$ of Cooperatives got assistance through model documents like constitution, codes of good practice and others accessed from the DoSD website.The consequent effect of poor communication has been a disadvantage to the NGOs located in the rural areas. Such NGOs may not be aware of the benefits that they can reap out of registration like tax exemption. For instance, of the 150000 NGOs operating countrywide, only 10000 have a Public Benefit Organisation number which exempts it from paying tax from SARS (NPO Voluntary Code, 2012).

According to institutional development, poor information communication does not help NGOs to be sustainable. According to McGill (1995) institutional development is hinged on the ability of the government to create an enabling environment and on the NGOs to develop a strong organisation that can sustain the poor. Moreover, central to the concept of sustainable development are elements of equity which touch on the fair distribution of resources and property rights both within and between generations. The fact that the well-established NGOs are the ones in a position to benefit contradicts the standpoint adopted by this study.

\subsection{Fragmented Registering Bodies.}

DoSD indicated that most Trusts and Section 21 companies have the privilege of accessing information and they manipulate it to their own advantage. According to the DoSD, there are some NGOs with dual or triple registrations. As a Section 21 or a Trust (to be able organisation to carry out fundraising activities), as a Public Benefit Organisation (to acquire the public benefits from SARS for tax exemption) and as a Cooperative to distribute profit among members. These irregularities require a revision of the legislative framework in order to curb activities such as these NGO members who are exploiting the loopholes within the system. The reason why cooperatives are allowed to distribute their proceeds is because there is a provision by the Department of Agriculture that cooperatives are those organisations where poor people join hands and do farming so that they can share their produce. Therefore, some people take advantage of such circumstances to make profit and share it while they also enjoy the benefits of being exempted from paying tax in the name of a PBO. An establishment of a single body which can carry out registration activities can help to curb such activities.

The challenge associated with the fragmented registration bodies is that they are more likely to put rural-based NGOs at a disadvantage. Urban-based NGOs are in a position to grow due to their proximity to information and the ability to manipulate opportunities, unlike the rural NGOs who often rely solely on government funding. When it comes to funding, any donor would prefer to give funding to an established organisation which they trust. Further, the state of the law that is governing registration is not what NGO authors subscribe to. Clayton (2007) in particular, argues that the role of the government is to give a foundation of law and a friendly policy environment for NGOs because it is the one that has the power to open avenues for them.

\subsection{Distortions in Funding.}

The sectors which receive most of government's funding are characterised by well-developed, formal NGOs, which tend to be more active in established, urban working class and middle class communities than in the poorer communities. Forty seven percent of social services NGOs and $42 \%$ of health NGOs are concentrated in the middle-income socioeconomic categories DoSD (2005).

The majority of NGOs in the health and social service sectors, which receive a lot of government funding, are concentrated in the middle-income categories and were established before 1994. They catered more for the white sector of the society, and possibly still do. According to Swilling \& Russell (2003) this may raise concerns about who benefits from government funding support for the health and social service sectors. The health sector got R634 million from private sector donors, development and housing R585 million, and education and research R490 million but the authors did not give the year in which this money was given (Swilling \& Russell, 2003). 
Although the government through the RDP committed itself to bring about equal opportunities between the blacks and whites by funding all NGOs irrespective of their background, their efforts are being stalled by inherent institutional impediments. The government did not make an attempt to address the challenges faced by rural based NGOs where the poor live. These smaller community-based NGOs have not been recognised because most existing databases have not been designed to capture them (Swilling \& Russell, 2003). This substantial sub-group is believed to have an important contribution to make to poverty alleviation by responding to immediate problems at community level far more quickly than any more formal structures, particularly the government. Anecdotally, their response would be particularly effective for the HIVIAIDS crisis, as they would be providing support and care to the poorest of the poor, who have few other channels of assistance (Swilling \& Russell, 2003). Therefore, it should be of major concern to the government given that the majority of these organisations remain informal and reside in rural areas. Moreover, Jalali (2008) argues that the government often appreciates NGOs when they fill the gap in provision of essential services hence the government should appreciate the services being rendered by NGOs by supporting them.

\subsection{Lack of skilled personnel.}

Most NGOs indicated that they do not have the expertise required to come up with a good proposal. At the same time, organisations like Section 21 are able to do that through hiring professionals. These organisations are often at a disadvantage because they cannot access technical knowledge and information especially through consultants because it is unaffordable for them. Most NGOs admitted that it is a very competitive venture to write a good business plan that can secure funding. Even though they might succeed in registration, they often struggle to come up with a good project proposal. Therefore, the possibility of these NGOs closing down is high given that the government is not offering assistance for training to these NGOs.

\subsection{Delayed Funding}

Besides delays in registration, NGOs expressed that there are problems in the funding disbursement process. According to the NGO Pulse (2009) complaints are coming from civil society that the NLDTF goes for long without distributing funds due to the fact that the board that sits for the selection of NGOs does not meet frequently because they are not full time employees. The delays have been questioned because the same members are compensated to the tune of R1.2 million per year. Some NGOs complained that the amount going as remuneration for the board members was too much given the fact that there are millions of voluntary workers who sacrifice the little that they get to visit orphans and AIDS victims for R12 00000 per year. At the same time, more than 500000 needy South Africans, many of them women and children, could be plunged into further desperation as many NGOs face a funding crisis. NGOs, which represent $30 \%$ of social services in the country, had R3 billion less to spend on crucial development issues in 2009 because of the recession (Bately, 2009). The Raphael Centre also reported in January 2012 that it had not yet received funding from NLDTF. A survey carried out by the South Africa Institute of Fundraising revealed that $16.6 \%$ of organisations polled had enough money to cover operating expenses while corporate funding had been cut by $42.3 \%$, the NLDTF cut down by $37.9 \%$.

On the contrary, institutional development is of the notion that institutions are central to sustainable and beneficial development. They create the policies, mobilise and manage the resources, and deliver the services which stimulate and sustain development. Development is not likely to be sustained if institutions which guide it are dysfunctional. Thus, sustainable development lies among other things in the ability of institutions to filter and guide the development process (McGill, 1995). Therefore, the way in which NLTDF operates is not in line with institutional development. In one extreme case, the money which was awarded to one NGO got lost because it was deposited into another NGO's account because their names were similar. Such cases, although isolated, demonstrate lack of effective verification measures on the part of funders.

\subsection{The Decision-Making process.}

The government reserves too much autonomy by having the power to decrease or withdraw funding from NGOs without consultation or defaulting on the part of NGOs according to the Social Service Profession Bill 110 of 1978. In addition, the Bill discriminates against NGO members by giving them stipends that are a far cry from their needs. Moreover, the stipend is used by NGO members for travelling when they visit bedridden patients and orphans. The Bill stipulates that only 10 members with a Matric pass can get R1000 00 per month and the rest get R600 00 per month. Although the 
motive of the government is not clear by so doing, the ceiling has caused conflicts. In Ethembeni there were more than 10 members who had Matric. They experienced conflicts within the organisation as members struggled to decide on who should get the stipend of R 1000, 00.

The funding model of the government seriously lacks substantial tools to measure sustainability. This is so because the government only gives what it feels it can give, for instance one NGO got R50 00000 after asking for R347 000 00. This makes it difficult for the government to measure sustainability; neither is it going to know if there is need to increase or decrease funding because the funding is not informed from below. Development can be deemed to be meaningful when the basic needs of the poor and marginalised are met through empowering them with lasting solutions that will make them self-sufficient (Schmale, 1993).

In a nutshell, the grant-making model that the government is using is not streamlined. The model does not speak to the needs of the people while NGOs are not quite informed of the modus operandi of the whole system. The need to translate the model into simplicity cannot be over emphasised. This is very crucial because NGOs will continue to grope in darkness while the government will also have a bad image with NGOs and this constitutes institutional weakness. McGill (1995) suggests that, institutional weakness constitutes a roadblock to development in developing countries. This problem of institutional weakness is reputed to be most severe in sub-Saharan Africa.

Another indirect effect of the existing principles is that the required pre-requisites which are business planning and accountability can easily be met by NGOs that were already thriving under the apartheid rule. In most cases, these NGOs are urban-based. Although some might have operational bases in rural areas, they have little impact on the poor. Since the existing funding strategy is better understood by this calibre of NGOs, the poor will continue to be marginalised because funding is falling into the wrong hands.

Mercier (1998) is of the opinion that NGOs have become important players in development. There is a shared consensus that NGOs have become popular with the donor agencies as channels because of the qualities that they have. These range from diversity, efficiency and ability to reach the grassroots people and their mobilisation for sustainable development on the use of natural resources as shown earlier. Jalali acknowledges that the volume of aid to NGOs has been on the increase, with the Organisation for Economic Cooperation and Development (OECD) giving between $15 \%$ and $20 \%$ of total overseas development aid channelled to NGOs. Although NGOs have become popular with global donors who wish to assist African countries in development as evidenced by the Mercier and Jalali, this has not been the case in South Africa. Although aid is being channelled, the beneficiaries are well established NGOs who have the ability to meet the requirements of the funding strategy.

Two NGOs that receive money from the DoSD claimed that they got approximately R550 000 per year despite their submissions of business plans that indicated their financial needs. This money is disbursed without the consideration of the needs at grassroots level, a reflection of lack of serious consultation and engagement at the grassroots level. This should not be the case because NGOs are founded on the need to assist the poor and powerless. Therefore, funding should not be rigid but speak to the needs of those that need assistance because if they do not get assistance they may resort to unsustainable means for survival.

Another complaint raised by the NGOs is that the government gives $10 \%$ of the funding as an initial payment. After this the NGO will have to account for the money before they can ask for the next batch. Moreover, for them to get the next tranche, they must submit another application stating what they want to use the money for. This sounds like a replication given the fact that the NGO would have already submitted a business plan stating their needs. This replication is time consuming and also taxing on the part of NGOs.

\subsection{Closures and Downsizing.}

The net effect of the funding crisis that has taken its toll on NGOs for a long time is now being felt in full force now. Many NGOs are compelled to look for solutions that can sustain them. What is of certainty is that funding has been shrinking and NGOs have to brace for the challenge. Some NGOs that are already considering closures include The Raphael Centre and a Western Cape based NGO called Rape Crisis. Despite the gap that they were filling, they may have to close by November if their situations do not improve. Laphumikwezi, in Fort Beufort closed because it failed to access funding due to registration complexities.

\section{Conclusion}

This paper demonstrated that the operations of NGOs are adversely affected by the existing funding strategy. Therefore, 
it is imperative for the government to engage with NGOs by supporting their work. Major challenges experienced by NGOs derive from the requirements of the funding strategy. The inability of the Social Development Directorate to carry out its functions is a reflection of lack of resources and capacity. There has been increased awareness among other governments that they cannot handle NGO registration and matters concerning the sector. Such governments have moved on to establish separate entities. In the United Kingdom (UK), regulation of NGOs is done by a Charity Commission which annually reports to the Home Secretary and Parliament. In 2002, in New Zealand, the government approved the establishment of a New Zealand Charities Commission which was assigned to approve and register NGOs, receive annual returns, monitor activities of NGOs and provide advice and support to the sector and to the government. The independence of the body was secured by the establishment of the Commission as a Crown Agency with a separate board (Morgan, 2005). The Social Service Professions Bill 110 of 1978 gives the government too much autonomy allowing it to withdraw funding from the NGOs without prior notice. There should be an established dialogue between the government and NGOs in terms of the way that each of them operate. The fact that the government retains an upper hand in terms of determining the amount that is allocated to NGOs is reminiscent of a top-down approach to development. There is need for the government to engage with the NGOs in areas of policy making and service delivery.

NGOs on the other hand must also consider strengthening their management skills to be able to sustain themselves in times of crisis. Moreover, it takes more than financial resources to create an organisation that can have a long lasting life (Tsikululu Social Investments, 2012). The need for good governance as well as adherence to good ethics can never be over emphasised in running a professional organisation. This include among other ethics, working for the good of the public given that NGOs will be operating as Public Benefit Organisations. Another avenue for NGOs could be merging with other NGOs to create resilience. Although this has challenges of its own in terms of branding identity, if taken for the good of the public, this can be one of the effective ways of avoiding closure. From the evidence presented in this article it can be noted that there is a multiplicity of challenges that NGOs are facing. These derive from the complex policies governing the funding of NGOs. In addition, the economic recession has also seen some donors reducing funding while others withdrew altogether. The crisis has also been further exacerbated by lack of managerial skills on the part of NGOs. While NGOs are compelled to strategise in order to face the challenges of funding, the government also has to revise the way in which NGOs are funded.

\section{References}

Abugre, C. 1994 NGOs, "Institutional Development and Sustainable Development in post-Apartheid South Africa" in Sustainable development for a democratic South Africa London:Earthscan.

Bately, M. 2009 "Lottery Funding and the NGO Sector".Accessed from www.ngopulse.org/lottery-funding-and-ngo-sector on 01/07/2009.

Bond, P. 2003. "Foreign Aid and Development debates in Post-apartheid South Africa".accessed from www.transformation.ukzn.ac.za/archive/tran045/tran0450003.pdf on 28/10/2009

Brown, L and Kalegaonkar, A 2002. "Support Organisations and the Evolution of the NGO sector" in Non Profit and Voluntary Sector Quartelyvolume 31 (2) pp 231-258. Christopher, A.J 1994. "The atlas of apartheid".Accessed from www.books.google.co.za /books on 23/06/2008.

Davids,I 2005, "The strategic role of development NGOs in Participatory development in South Africa. A development management perspective". Van Shaik: Pretoria

Department For International Development, 2003. "Promoting Institutional and Organisational Development".London: DFID.

Department of Social Development. 2009. Governance Report. Accessed from www.dsd.gov.za on 18/10/2010.

Department of Social Development. 2005. NPO Impact Assessment. Accessed from www.dsd.gov.za on 23/08/2009.

Department of Social Development. 2009. The State of NPO Registration. Accessed from www.dsd.gov.za on 15/112009.

Department of Social Development. 2010. "Literature Review on Developing Good Governance Practices". Accessed from www.dsd.gov.za on 15/112009.

Duggard ,J.Hayson, N. and Marcus,G. 1992. "The Last Ten Years of Apartheid: Civil Liberties In South Africa". Copublished by Ford Foundation and Foreign Policy Association. United States of America

Gibbs, C.J.N, Funo, C. and Kuby, T. 1999, "Nongovernmental Organisations in World Bank-Supported Projects".Washington D.C. USA. International Bank for Reconstruction and Development and World Bank.

Habib, A. 2003, "State- Civil Society relations in post-apartheid South Africa" in State of the Nation: South Africa 2003-2004 eds Daniel J, Habib A and Southall R. Cape Town. Human Sciences Research Council.

Habib, A. and Taylor, R. 1999. "South Africa: anti-apartheid NGOs in transition" in Voluntas: international journal of voluntary organisations 10 (1) pp 73-82. Accessed from www.ingentaconnect.com on 10/04/2008.

Heltberg, D.R. 2001, "Methods for Studying Collective Action in Rural Development" in Agricultural Systems Journal volume 82 (3) pp 197-354.

Jalali, R. 2008. "International Funding of NGOs in India: Bringing the State Back In" in Voluntas Journal 19 pp 161-188. 
Julie, F. 2009. "The Roots of the NGO Crisis: A Look Beyond the Surface" in NGO Pulse Kiggundu, M. N, Jorgensen J.J and Hafsi T. 1983. "Administrative Theory and Practice in developing countries: 'a synthesis'" in Administrative Science Quarterly Journal 28 (1) pp 66-84.

Kironde, S. and Neil, S. 2004. "Indigenous NGO involvement in TB treatment programmes in high-burden settings: experiences from the Northern Cape Province, South Africa" in International Journal of Tuberculosis and Lung Disease volume 8(4) pages 504-508 accessed from http//www.docstore.ingenta.com/cgi-bin/ds-deliver on 24/09/2008

Leornard, K.L. 2002. "When both states and markets fail: asymmetric information and the role of NGOs in African health care" in International Review of Law and Economics Journal 22 (1) pp 1-196.

Lu, Y. 2005. "The Limitations of NGOs: a preliminary study of non-governmental social welfare organisations in China". In Need and Entitlement: New Approaches to Social Policy in China's Transition. Labour and Social Security Publishing House. China

Machenjedze, N. 2008 "An investigation of public participation in public policy formulation in South Africa".Unpublished Honours Mini dissertation, University of Fort Hare, South Africa.

McFubara, K.G. 2002. "Making African NGOs more responsive to social needs" in Journal of Social Development in Africa. 17 (1) pp 39 58.

McGill R. 1995. "Institutional Development: a review of the concept" in International Journal of Public Sector Management 8 (2) pp 63-79

Mercier, C. 1998. "Reconceptualising state-society relations in Tanzania: are NGOs 'making a difference?" in Area 31 pp $247-258$.

Michael, S. 2004. "Undermining Development The absence of power among local NGOs in Africa, African Issues".Oxford.JamesCurrey.

National Development Agency Act of 1998.Accessed from www.info.gov.zalactsl1998197-98.pdf on 08/09/2009.

National Development Agency.Accessed from www.aidsbuzz.org/funding/governement-funding.html on 08/09/2009.

Nauta, W.1998, "The Implications of Freedom". LIT Verbag Berlin-Hamburg-Munster. Berlin.

Non Profit Organisations Directorate PowerPoint Presentation accessed from www.iccsl.org/pubs/NPODirectoratepresentation.ppt on 18/10/2010

Parkhurst, J.O. \& Lush L. 2004. "The Political environment of HIV: lessons from a comparison of Uganda and South Africa". In Social Science and Medicine Journal.Pp 1913-1924.

Penderis, M. 2006. "South Africa: NGOs search for their place" in Africa News Update.

Pieterse, E. 1997."South African NGOs and the trials of transition" in Development in Practice 7 (2) pp 157-166.Taylor and Francis.accessed from www.jstor.org/stable/4028891 on 21/02/2009

Pieterse, E. 2003."Rhythms, patterning and articulations of social formations of South Africa" in The Real State of the nation.South Africa After 1990 edited by Everat, D and Maphai V. Interfund Development Update, South Africa.

Reconstruction \& Development Programme Act accessed from www.info.gov.zalactsl1994197-94.pdf on 28/09/2008

Rural Livelihoods. 2007. "HIV \& AIDS Home Based Care Consultative Conference Report". East London. RULIV.

Schmale, M. 1993 "The role of local organisations in third world development: Zimbabwe, Tanzania and Ethiopia". AveburyAshgate publishing: England.

Schneider, H. and Gilson, L. 1999. "Small fish in a big pond? : External aid and the health sector in South Africa" in Policy and Planning Journal 14 (3) pps 264-272. Oxford, London. Oxford University Press.

Srinivas, H. Fund Raising Realities and Strategies: Lessons Learnt at the NGO Cafe (unpublished).

Swilling, M and Russell, B. 2003."The Size and Scope of the South African Non-Profit Sector". South Africa. Centre for Civil Society, the Graduate School of Public Development and Management University of Witwatersrand and University of Natal.

Terreblanche, S.J 2002. "A History of Inequality in South Africa 1652-2002". University of Natal Press.

Tsikhululu Social Investments. 2012. "Wanted: Resilient NGOs". Accessed from www.devbox.virtuosa.co.za accessed 27/10/2012.

Tvedt, T. 1998. "Angels of Mercy or Development Diplomats?NGOs and Foreign Aid". Trenton. Africa World Press. 